University of Northern lowa

UNI ScholarWorks

Faculty Publications

$11-21-2021$

\title{
To the Side, to the Side: Academic Libraries and LibGuides Layout Adoption
}

Chris Neuhaus

University of Northern lowa, chris.neuhaus@uni.edu

Anne Marie Gruber

University of Northern lowa, anne.gruber@uni.edu

See next page for additional authors

Let us know how access to this document benefits you

Copyright (C2021 Chris Neuhaus et al.

Follow this and additional works at: https://scholarworks.uni.edu/facpub

Part of the Library and Information Science Commons

\section{Recommended Citation}

Neuhaus, Chris; Gruber, Anne Marie; Cox, Angie; Koh, HyunSeung; Kelly, Jim; Bowling, Claire; and Bunz, Gail, "To the Side, to the Side: Academic Libraries and LibGuides Layout Adoption" (2021). Faculty Publications. 3959.

https://scholarworks.uni.edu/facpub/3959

This Article is brought to you for free and open access by UNI ScholarWorks. It has been accepted for inclusion in Faculty Publications by an authorized administrator of UNI ScholarWorks. For more information, please contact scholarworks@uni.edu. 


\section{Authors}

Chris Neuhaus, Anne Marie Gruber, Angie Cox, HyunSeung Koh, Jim Kelly, Claire Bowling, and Gail Bunz 


\title{
To the Side, to the Side: Academic Libraries and LibGuides Layout Adoption
}

\author{
Chris Neuhaus, Anne Marie Gruber, Angie Cox, \\ HyunSeung Koh, Jim Kelly, Claire Bowling and Gail Bunz
}

\section{QUERY SHEET}

This page lists questions we have about your paper. The numbers displayed at left are hyperlinked to the location of the query in your paper.

The title and author names are listed on this sheet as they will be published, both on your paper and on the Table of Contents. Please review and ensure the information is correct and advise us if any changes need to be made. In addition, please review your paper as a whole for typographical and essential corrections.

Your PDF proof has been enabled so that you can comment on the proof directly using Adobe Acrobat. For further information on marking corrections using Acrobat, please visit http://journalauthors.tandf.co.uk/production/acrobat.asp; https://authorservices.taylorandfrancis.com/how-to-correct-proofs-with-adobe/

The CrossRef database (www.crossref.org/) has been used to validate the references. Changes resulting from mismatches are tracked in red font.

\section{AUTHOR QUERIES}

Q1 Citation [Thorngate and Hoden, 2017] has been updated. OK?

Q2 Citation [Conerton and Goldenstein, 2017] has been updated. OK?

Q3 Please provide reference for citation [Indiana University Center for Postsecondary Research, 2018].

Q4 The disclosure statement has been inserted. Please correct if this is inaccurate.

Q5 References [Barker and Hoffman, 2021; Bergstrom-Lynch, 2019; Gonzalez and Westbrock, 2010; Kingsburg and Andre, 2004; Logan and Spence, 2021; Neuhaus et al., 2021; Pionke and Manson, 2018; Pittsley and Memmott, 2012; Salmerón et al., 2017; Sonsteby and DeJonghe, 2013; Thorngate and Hoden, 2017; Bernard, 2001; Bowen, 2014; Chan et al., 2019; Conerton and Goldenstein, 2017; Dalton and Pan, 2014; Del Bosque and Morris, 2021; Duncan et al., 2015; Foster et al., 2010] have been updated. OK?

Q6 Please provide missing [conference location/publisher name] for [Burrell and Sodan, 2006].

Q7 Please provide missing [publisher name] for [Fessenden, 2017].

Q8 Please provide missing [conference location] for [Holzinger et al., 2011]. 
Q9 Please provide missing [Issue/page number/volume number] for [Kalbach and Bosenick, 2003].

Q10 Please provide missing [publisher name] for [Markman, 2016]. 


\title{
To the Side, to the Side: Academic Libraries and LibGuides Layout Adoption
}

\author{
Chris Neuhaus, Anne Marie Gruber, Angie Cox, HyunSeung Koh, Jim Kelly, \\ Claire Bowling, and Gail Bunz
}

Rod Library, University of Northern lowa, Cedar Falls, lowa, USA

\begin{abstract}
In 2014, Springshare introduced a new LibGuides layout option. In addition to the traditional horizontally-tabbed layout (top navigation), LibGuides designers now have the option of vertically-arrayed tabs on the upper left-hand side of the page (side navigation). Like the university hosting this study, schools have, to varying degrees, shifted their LibGuides toward side navigation and away from top navigation. To better understand the research behind this migration, researchers at the University of Northern lowa conducted a thorough literature review on navigation menu location preferences and navigation menu efficacy within the field of librarianship and computer science. This review identified a complex and diverse set of results not often reported in the library literature. To gauge the extent of migration toward side navigation in LibGuides, this study investigated the navigation layout of the ten most visited LibGuides at 462 academic libraries throughout the United States during the summers of 2019 and 2021. While the majority of the LibGuides reviewed at research universities are now in side navigation format, the adoption rate of side navigation in LibGuides differed dramatically by the size and type of academic institution.
\end{abstract}

\section{KEYWORDS}

Academic libraries; libguides; side navigation; website design; carnegie classification

\section{Introduction}

Springshare LibGuides have become a familiar resource throughout the library world. Springshare claims more than 6,000 libraries are customers of its products (i.e., LibGuides, LibAnswers, LibCal LibInsight, and LibWizard) (Springshare, 2021a). From the LibGuides Community website, Springshare announces that more than 5,000 institutions are offering more than 800,000 LibGuides created by more than 200,000 librarians (Springshare, 2021b). The library literature features hundreds of LibGuides-focused journal articles across topics ranging from accessibility, assessment, and implementation, to instruction, marketing, and outreach (e.g., Bowen, 2014; Dalton \& Pan, 2014; Foster et al., 2010; German et al.,

CONTACT Chris Neuhaus chris.neuhaus@uni.edu $\Theta$ Rod Library, University of Northern lowa, Cedar Falls, lowa, USA, 
2017; Kerico \& Hudson, 2008; Pionke \& Manson, 2018). A rich and wellcited portion of this literature concentrates on usability testing and best practices for LibGuides design (e.g., Bergstrom-Lynch, 2019; Bowen et al., 2018; Chan et al., 2019; Conerton \& Goldenstein, 2017; Gonzalez \& Westbrock, 2010; Goodsett et al., 2020; Ouellette, 2011; Pittsley \& Memmott, 2012; Sonsteby \& DeJonghe, 2013; Thorngate \& Hoden, 2017).

The current study focuses on one specific aspect of LibGuides design and implementation - side navigation - where navigational tabs are positioned in the upper-left portion of the page. Side navigation is also known as left-side navigation, left-hand navigation, vertical navigation, or even side-nav. This design is often contrasted with top navigation, where navigational tabs are positioned horizontally across the top of the page. Top navigation is also referred to as tabbed navigation or horizontal navigation. Articles proposing LibGuides design best practices have encouraged the creation of LibGuides that feature side navigation (Bergstrom-Lynch, 2019; Duncan et al., 2015; Goodsett et al., 2020).

\section{Literature Review}

To better understand how many libraries are now utilizing the side navigation layout in their LibGuides, and why they are doing so, this study reviewed the empirical evidence supporting this transition, and documented the progression to side navigation among four different types of academic libraries (as defined by Carnegie Classification).

Some studies have concluded that side navigation is preferred by users. Other studies found that side navigation is a more effective menu format. However, a review of usability studies that test internal navigation link locations for either web pages or LibGuides reveals a complex picture; not all results conform to these two conclusions. Additionally, many of the studies found in the library literature rely on small sample sizes. Library science studies on LibGuides navigation menu location included in this literature review had sample sizes ranging from 5 to 26 participants. Computer science studies on web page navigation menu locations have generally been more robust with sample sizes that ranged from 13 to 841 participants, including four studies with sample sizes over 100. Some researchers believe that website navigation needs more investigation. After reviewing thirteen menu-positioning studies, Murano and Sander (2016, p. 355) concluded that "despite the opinions and numerous studies around this subject, there are still unanswered questions regarding which menu position or design might be optimal in terms of performance and user preference." The following review of past research on navigation menu location may also indicate a need for further study. 
As early as 2001, in a study of 346 participants, Bernard found that most "expected the links to web pages within a website to be almost exclusively located on the upper left-hand corner of a web page" (Bernard, 2001, p. 1162). Kalbach and Bosenick (2003) timed two groups of 32 participants who completed five different tasks using either a side navigation menu or a right-side menu. They found no differences in the time-to-completion between the two groups. In a questionnaire and usability test involving 164 participants, Pratt et al. (2004) found a statistically significant user preference for vertical navigation (another name for side navigation), but found no statistically significant difference in task completion time between vertical and top navigation layouts. Kingsburg and Andre (2004) conducted usability tests using various navigation menu locations, finding that the sixteen undergraduate participants completed navigational tasks more quickly with a side navigation menu. McCarthy et al. (2004) studied the impact of navigation menu positioning (left, top, and right) and found that, while the 31 participants performed better with left-side navigation (side navigation) on their first visit, any difference in performance disappeared with subsequent visits. They conclude that "violating expectation of menu position on Web pages has little long-term impact on task performance when searching a single page" (McCarthy et al., 2004, p. 412). Burrell and Sodan (2006) looked at both preferences for navigation menu location and the possible impact menu placement may have on task completion. They found that their 16 participants did prefer a side navigation menu location, but that location did not have a significant impact on web page usability.

Holzinger et al. (2011) found that placing actionable elements on the left side of a screen rather than the right side significantly decreased the selection time for the 50 participants in this study, but only in cases where a single option was to be chosen. For pages with multiple actionable elements, there was no statistically significant difference in selection time between pages with options on the left side and options on the right side. Noting Hick's Law which posits a direct relationship between reaction time and the number of possible alternatives on a web page, the authors suggest that reaction times for multi-option menus would be similar regardless of the location on the page. Murano and Oenga (2012) studied task completion time, navigation errors, reported ease of use, and participant satisfaction among 56 undergraduates working with three different navigation menu types. This study found no significant differences between the side navigation menu and the (top) horizontal menu for any of the variables under consideration. A usability test by Hernandez and McKeen (2015) found that the five participants clicked more frequently on a librarian profile box if it was located on the left side of LibGuides even though the study did not show a clear preference for side navigation versus horizontal navigation. 
Q1 Thorngate and Hoden (2017) found six of fifteen participants could recall the location of a side navigation menu after only a brief five-second view of LibGuides. In contrast, none of the fifteen participants who briefly viewed the top navigation LibGuides could then recall the location of the navigation menu. In the "think aloud" portion of this study, all fifteen students working with a side navigation LibGuides could locate the navigation menu and complete a given task. Only thirteen of the fifteen students could complete the same task with a horizontal tabbed LibGuides. In another portion of this study, eight students took a usability test that included the ability to locate the navigation menu. There were no differences in performance detected between participants given the side navigation and the top navigation settings.

In their study of preference for the location of web interface elements, Heinz et al. (2017) found that most of their 841 participants expected the navigation area to be on the left side of the website. Fessenden (2017) reflected on eyetracking studies performed both in 2010 and 2017 and found that while websites have evolved, the 120 participants in the 2017 experiment still spent $94 \%$ of their attention on the left-hand side of web pages. Librarians at Harvard University compared user behavior for 26 participants on side navigation LibGuides compared with horizontal-tabbed LibGuides using eyetracking techniques. They found that the average time to the first fixation on the navigation menu was faster for side navigation than a horizontal tabbed menu (top navigation). In addition, the Harvard study found that the average time spent looking at the menu ("fixation duration") was greater for side navigation compared with top navigation menus (Markman, 2016).

Conerton and Goldenstein (2017) interviewed eight students regarding their preference for side navigation versus top navigation. They found at least half of the participants preferred top navigation even though the researchers pointed out that an aversion to scrolling, required for the side navigation LibGuides under consideration, might have been a factor. Salmerón et al. (2017) found that their participants favored right-side menus for Arabic language websites but expressed no clear preference for left-side or right-side menus on English language websites. Chan et al. (2019) found that eight undergraduate students expressed a preference for a top navigation format, five preferred a side navigation layout, and one student expressed no preference. Barker and Hoffman (2021) found that nine undergraduates expressed a preference for top navigation, seven preferred side navigation, and two expressed no preference.

\section{Current Study}

To date there have been no extensive studies analyzing side navigation adoption in LibGuides. In response, this study investigates the current extent of side navigation implementation, the rate of migration from top navigation to side 
navigation, and possible differences in side navigation adoption between various types of academic libraries. This study examines the following three specific research questions:

Q1. What percent of the ten most visited LibGuides use side navigation for 165 each of the libraries drawn from a specific Carnegie Basic classification?

Q2. Are there differences in the degree of side navigation adoption between groups of libraries from different Carnegie Basic classifications?

Q3. Has the percentage of the ten most visited LibGuides using side navigation changed over the past two years for the libraries under consideration?

\section{Methodology}

This two-year study of side navigation implementation in LibGuides began as one of many facets of a larger project (Neuhaus et al., 2021) to analyze online library guides for all the libraries within four different Carnegie classifications as defined by the 2019 Carnegie Standard Listings (Indiana University Center for Postsecondary Research, 2018). The following four Carnegie Basic classifications were selected from the thirty-three possible categories both to provide a variety of academic environments for consideration and to include the maximum number of institutions from the authors' home state of Iowa:

- "Doctoral Universities: Very High Research Activity." The 91 universities studied in this category, out of a possible total of 132 universities listed within this classification, will be referred to in this study as doctoral-level institutions.

- "Master's Colleges \& Universities: Larger Programs." The 215 universities studied in this category, out of a possible total of 351 universities listed within this classification, will be referred to in this study as master's-level institutions.

- "Baccalaureate Colleges: Arts \& Sciences Focus."The 118 colleges studied in this category, out of a possible total of 241 colleges listed within this classification - will be referred to in this study as baccalaureate-level institutions.

- “Associate's Colleges: Mixed Transfer - Career \& Technical - High Traditional."The 38 colleges studied in this category, out of a possible total of 112 colleges listed within this classification, will be referred to in this study as associate's-level institutions. 
While all academic libraries from each of the four chosen classifications were initially under consideration, a library was considered for this study only if it met the following three criteria:

- The library offered LibGuides.

- The library provided a means for ranking LibGuides by number of visits.

- The library was clearly the primary sponsor when LibGuides were shared among a group of libraries.

Upon inspection 462 libraries met these requirements. As a result, libraries from 91 doctoral-level institutions, 215 master's-level institutions, 118 baccalaureate-level institutions, and 38 associate's-level institutions were included in this study.

For each institution, the primary directory of LibGuides was located and ranked by the number of guide visits using either the "By Popularity" option found under the "All Guides" setting or by affixing the URL suffix $? b=g \nLeftarrow d=p$ to the end of the LibGuides directory address. Each of the ten most visited LibGuides was then inspected to determine if it was in side navigation format. This tally of side navigation adoption in the ten most visited LibGuides was repeated twice - first during the summer of 2019 - and then, two years later, in the summer of 2021.

\section{Results}

The analysis of the ten most visited LibGuides provided by all of the libraries within the four different Carnegie classifications under consideration yielded a number of findings. In relation to the first and second research questions, the frequency of side navigation format for LibGuides varied significantly by type of institution. In particular, the 2021 review of these libraries revealed that $58 \%$ of the doctoral-level LibGuides, $43 \%$ of the master's-level LibGuides, 36\% of the baccalaureate-level LibGuides, and $28 \%$ of the associate's-level ten most visited LibGuides are in side navigation format (FIGURE 1).

In relation to the third research question, there was also a very discernible increase in the percentage of the ten most visited LibGuides in side navigation format between 2019 and 2021 for all classifications of libraries studied. The increase in side navigation format for the ten most visited LibGuides from 2019 to 2021 was from $49 \%$ to $58 \%$ for doctoral-level institutions, from $33 \%$ to $43 \%$ for master's-level institutions, from $25 \%$ to $36 \%$ for baccalaureate-level institutions, and from $16 \%$ to $28 \%$ for associate's-level institutions (FIGURE 1).

Similar trends across Carnegie classifications were observed when tallying the number of libraries with most of their ten most visited LibGuides (six or more guides) in side navigation format. In this case, $53 \%$ of doctoral-level 


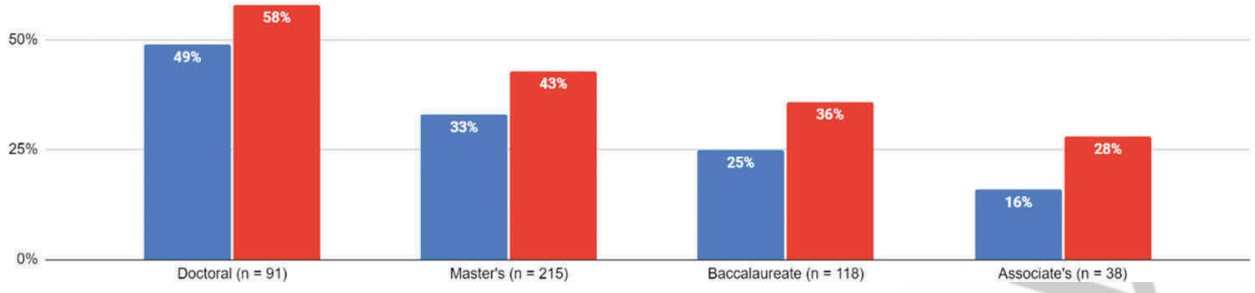

Figure 1. Percent of Ten Most Visited LibGuides in Side Navigation Format.

institutions, $40 \%$ of the master's-level institutions, $29 \%$ of the baccalaureatelevel institutions, and $18 \%$ of the associate's-level institutions had a majority of their ten most visited LibGuides in the side navigation format. A comparison of libraries with a majority of top-ten LibGuides in side navigation format shows an upward trend for all four classifications from 2019 to 2021240 (FIGURE 2).

A graph documenting the frequency of side navigation LibGuides among the ten most visited guides reveals a distinct bimodal distribution. Many libraries either have all of their ten most visited LibGuides or none of their ten most visited LibGuides in the side navigation format (FIGURE 3). The distribution of libraries featuring only side navigation format within their ten

Percent of Libraries with a Majority of Their Ten Most Visited LibGuides in Side Navigation Format

\section{(Six to Ten Side-Nav Guides)}

$2019 \square 2021$

$100 \%$

$75 \%$

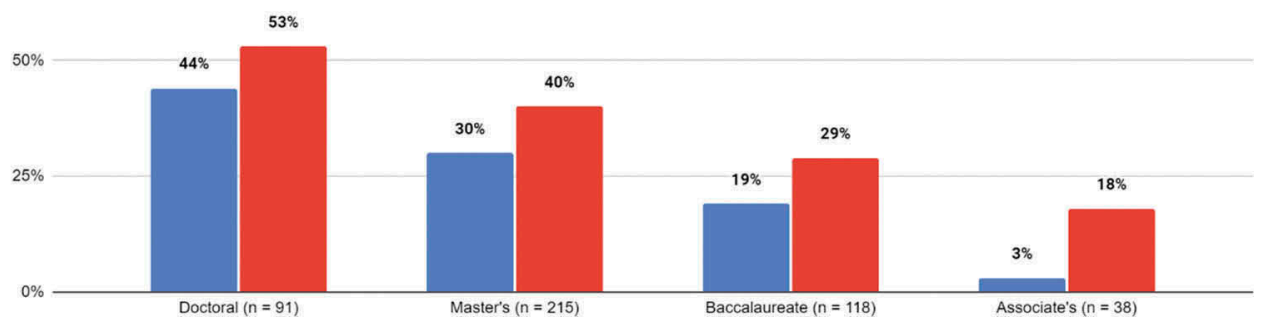

Figure 2. Percent of Libraries with a Majority of Their Ten Most Visited LibGuides in Side Navigation Format (Six to Ten Side-Nav Guides). 


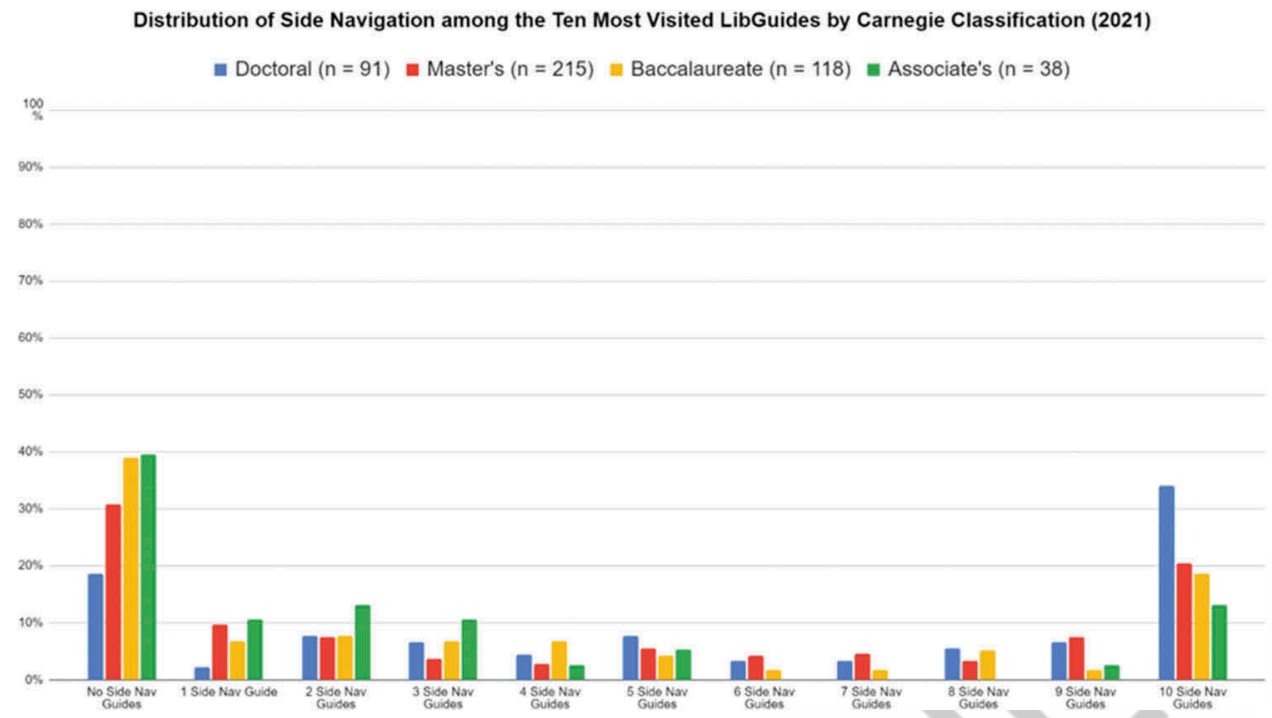

Figure 3. Distribution of Side Navigation among the Ten Most Visited LibGuides by Carnegie Classification.

most visited LibGuides was 34\% for doctoral-level institutions, $20 \%$ for master's-level institutions, $19 \%$ for baccalaureate-level institutions, and $13 \%$ for associate's-level institutions.

Conversely, the distribution of libraries without any of their ten most 250 visited LibGuides in side navigation format trends in the opposite direction. Only $16 \%$ of doctoral-level institutions, $31 \%$ of master's level institutions, $40 \%$ of baccalaureate-level institutions, and $40 \%$ of associate's-level institutions fail to feature side navigation on any of their ten most visited LibGuides.

\section{Discussion}

This study demonstrates that advice from the library literature (BergstromLynch, 2019; Duncan et al., 2015; Goodsett et al., 2020) to migrate to side navigation menus has been heeded by most of the doctoral-level libraries under consideration. More than $50 \%$ of the ten most visited guides offered by these doctoral-level libraries now feature side navigation. In addition, 34\% of the doctoral-level libraries included have all of their ten most visited guides in side navigation format. This study also found that the three other categories of libraries considered saw increases in side navigation over the past two years. Whether through conversion from top navigation to side navigation, or by the creation of new LibGuides in side navigation format, the total number of ten most visited LibGuides with side navigation, for all schools in this study, increased from 1,509 guides in 2019 to 1,977 
guides in 2021. During this period the proportion of ten most visited guides with side navigation increased $9 \%$ for doctoral-level libraries, $10 \%$ for master's-level libraries, $10 \%$ for baccalaureate-level libraries, and $12 \%$ for associate's-level libraries.

Though the past two years have seen a steady move to side navigation for all the library categories under consideration, the differences among categories are considerable. Remaining questions include: What are the possible reasons for significant disparities in side navigation deployment among Carnegie classes? And why do larger schools have greater percentages of side navigation among their most used LibGuides? At least two theories might explain why larger doctoral level institutions have more of their most popular LibGuides in side navigation format. Larger schools may be more likely to have specific LibGuides design standards. Larger schools may also have more time to devote to LibGuides conversion.

Recent research on the implementation of LibGuides standards touches upon LibGuides layout. In their survey of content strategy implementation for LibGuides, Logan and Spence (2021) found that $53 \%$ of the 120 responding institutions indicated that their libraries had content guidelines and that $73 \%$ of those respondents had guidelines for navigation. Thus, the institutions replying to this survey could require that their guides all appear in side navigation format, though this study did not specify which navigational option (side navigation or top navigation) was required. Though the majority of respondents in this study, 63 of 120, were "doctorate-granting" universities, this study did not report the percentages of LibGuides navigation guidelines based on the type of participating school (e.g., master's, baccalaureate, and associate's institutions). Del Bosque and Morris (2021) surveyed both LibGuides administrators and LibGuides authors from member libraries of the Greater Western Library Alliance to determine how members were using LibGuides. They found $43.73 \%$ of the authors and $28.57 \%$ of the administrators reported that their institution required compliance with a specific LibGuides style guide. In addition, $16.84 \%$ of the LibGuides administrators responded that their institution required a particular LibGuides layout, though the nature of that layout (e.g., requirements for side navigation) was not specified. However, even if side navigation was an institutionally required LibGuides element, $62 \%$ of the LibGuides administrators reported that they found it difficult to get their colleagues to comply with the established LibGuides standards. This led the authors to conclude that "standards have clearly not been an effective way at keeping LibGuides at their best" and that "LibGuides are like the Wild West - rogue authors are everywhere, there is little control, and even the Sheriff questions how much enforcement they can provide." (Del Bosque \& Morris, 2021, p. 19). Both of these studies indicate that a proportion of doctoral level institutions now have LibGuides layout requirements and possibly even side navigation requirements that may either 
be complied with or ignored. However, more research into possible LibGuides standardization at smaller institutions is needed to determine if this plays a role in side navigation implementation at these schools.

Perhaps the decision to use side navigation simply comes down to a matter of time. With basically identical editing processes, building new LibGuides in either side navigation or top navigation format should take about the same amount of time. However, converting existing top navigation LibGuides to side navigation could be considered additional time spent on otherwise completed projects. While Springshare has made the act of resetting LibGuides from "Tab Layout" (top navigation format) to "Side-Nav Layout" (side navigation) a quick and easy command in the Guide Navigation Layout editing command box, once the Guide Navigation Layout is switched designers may find that the original content still needs considerable modifications. A library with many LibGuides in top navigation format will likely need to devote a significant amount of time to convert these guides to side navigation. If libraries remain unaware or unconvinced of the arguments for side navigation, a time-consuming LibGuides conversion project would not be a priority. Even if persuaded by the literature that side navigation is a desirable target, smaller libraries may simply not have enough time and staff available to devote to library guide redesign.

The present study, perhaps the first to investigate the implementation of side navigation in LibGuides over time and on a large scale, found that many libraries, especially doctoral institutions, are transitioning toward a side navigation design. What this study did not discover is why this transition is taking place. It's unclear whether this gradual move to side navigation is based on web standards of the institution, local surveys and tests of user experience, the natural tendency to follow the example of others - particularly if those setting the example are highly regarded institutions, or a response to the literature. What this study did discover is that the literature - when looked at thoroughly - may not provide a clear message.

The variety and diversity of findings among the seventeen navigation menu location studies reviewed in this paper, coupled with the fact that many of the studies were conducted with very small sample sizes, is perhaps an indication that additional research is needed on this question. Seven of the studies reviewed found preferences or expectations for a side navigation menu (Bernard, 2001; Burrell \& Sodan, 2006; Fessenden, 2017; Heinz et al., 2017; Markman, 2016; Pratt et al., 2004; Thorngate \& Hoden, 2017). However, five studies did not detect a clear navigation menu preference (Barker \& Hoffman, 2021; Chan et al., 2019; Conerton \& Goldenstein, 2017; Hernandez \& McKeen, 2015). Two of the studies reviewed found users performed better with side navigation menus (Kingsburg \& Andre, 2004; Thorngate \& Hoden, 2017). Two additional studies found conditional benefits of side navigation, but in one case only for first visits to a website (McCarthy et al., 2004) and in another 
case only when a single choice was presented (Holzinger et al., 2011). Four studies found no differences in user performance based on navigation menu location (Burrell \& Sodan, 2006; Kalbach \& Bosenick, 2003; Murano \& Oenga, 2012; Pratt et al., 2004). Despite this potential uncertainty, the current advice within the library world is to build LibGuides with side navigation and convert existing LibGuides with horizontal tabbed navigation to a side navigation display (Bergstrom-Lynch, 2019; Duncan et al., 2015; Goodsett et al., 2020). Findings from this study show this transition is taking place, albeit at different rates for different types of institutions.

\section{Limitations}

This study analyzed libraries from four of the possible thirty-three Carnegie Basic Classification categories. While collectively the libraries of other doctoral, master's, baccalaureate, and associate's categories may display LibGuides navigation menu patterns that are similar to that of the four specific categories under consideration, only additional research can confirm this. In addition, no Special Focus or Tribal Colleges categories were reviewed at any point in this research.

This study considered the ten most visited LibGuides from each institution. Stratified random sampling across the four chosen Carnegie categories to select guides for analysis from a universe of roughly 99,000 publicly available LibGuides could have yielded additional interesting, if decidedly timeconsuming, insights.

This study was also limited to those schools for which a ranking of LibGuides popularity could be ascertained. Smaller local or regional affiliates of a larger state university or academic consortium who offered LibGuides created by other institutions were also dropped from consideration. Thus only $71 \%$ (or 462 of a possible 655) institutions offering LibGuides from these four Carnegie categories were evaluated.

\section{Conclusion}

LibGuides are attractive because they can potentially save time, both for patrons and librarians. They allow librarians to rapidly produce instructional materials and portals to otherwise obscure information. LibGuides are popular because they can potentially magnify the reach of the library so as to better serve more members of the community. Are LibGuides, in fact, performing these noble tasks? Are they saving librarians time and enabling our patrons? Only additional research can answer these questions. Future studies that identify indicators of LibGuides effectiveness and impact are crucial. A decision to pay for and create LibGuides should be based on evidence that LibGuides do positively impact the community they are intended to serve. 
Since LibGuides are intended to be efficient, a decision to devote significant librarian time to modifying large numbers of guides should also be based on solid empirical evidence that these modifications will have a positive impact on their intended audience. Additional research is necessary to determine if the trend toward LibGuides side navigation is warranted, given mixed user experiences in the literature as well as the time required to design or redesign guides. Any LibGuides research and best practices that can identify efficient opportunities for improving patron services would be well-received as libraries make a case for their continued role in the future of higher education.

\section{Disclosure statement}

No potential conflict of interest was reported by the author(s).

\section{DEferences}

Barker, A. E., \& Hoffman, A. T. (2021). Student-centered design: Creating LibGuides students can actually use. College and Research Libraries, 82(1), 75-91. https://doi.org/10.5860/crl.82. 1.75

Bergstrom-Lynch, Y. (2019). LibGuides by design: Using instructional design principles and user-centered studies to develop best practices. Public Services Quarterly, 15(3), 205-223. https://doi.org/10.1080/15228959.2019.1632245

Bernard, M. L. (2001). Developing schemas for the location of common web objects. Proceedings of the Human Factors and Ergonomics Society Annual Meeting, 45(15), 1161-1165. https://doi.org/10.1177/154193120104501502

Bowen, A. (2014). LibGuides and web-based library guides in comparison: Is there a pedagogical advantage? Journal of Web Librarianship, 8(2), 147-171. https://doi.org/10. 1080/19322909.2014.903709

Bowen, A., Ellis, J., \& Chaparro, B. (2018). Long nav or short nav? Student responses to two different navigational interface designs in LibGuides version 2. The Journal of Academic Librarianship, 44(3), 391-403. https://doi.org/10.1016/j.acalib.2018.03.002

Burrell, A., \& Sodan, A. C. (2006, April). Web interface navigation design: Which style of navigation-link menus do users prefer? Proceedings of the 22nd International Conference on Data Engineering Workshops, ICDEW. https://doi.org/10.1109/icdew.2006.163

Chan, C., Gu, J., \& Lei, C. (2019). Redesigning subject guides with usability testing: A case study. Journal of Web Librarianship, 13(3), 260-279. https://doi.org/10.1080/19322909.2019. 1638337

Conerton, K., \& Goldenstein, C. (2017). Making LibGuides work: Student interviews and usability tests. Internet Reference Services Quarterly, 22(1), 43-54. https://doi.org/10.1080/ 10875301.2017.1290002

Dalton, M., \& Pan, R. (2014). Snakes or ladders? Evaluating a LibGuides pilot at UCD Library. The Journal of Academic Librarianship, 40(5), 515-520. https://doi.org/10.1016/j.acalib. 2014.05.006

Del Bosque, D., \& Morris, S. E. (2021). LibGuide standards: Loose regulations and lax enforcement. The Reference Librarian, 62(1), 1-22. https://doi.org/10.1080/02763877.2020. 1862022 
Duncan, V., Lucky, S., \& McLean, J. (2015). Implementing LibGuides 2: An academic case study. Journal of Electronic Resources Librarianship, 27(4), 248-258. https://doi.org/10.1080/ 1941126X.2015.1092351

Fessenden, T. (2017, October 22). Horizontal attention leans left. Nielsen Norman Group. https://www.nngroup.com/articles/horizontal-attention-leans-left/

Foster, M., Wilson, H., Allensworth, N., \& Sands, D. T. (2010). Marketing research guides: An online experiment with LibGuides. Journal of Library Administration, 50(5-6), 602-616. https://doi.org/10.1080/01930826.2010.488922

German, E., Grassian, E., \& LeMire, S. (2017). LibGuides for instruction: A service design point of view from an academic library. Reference \& User Services Quarterly, 56(3), 162-167. https://doi.org/10.5860/rusq.56n3.162

Gonzalez, A. C., \& Westbrock, T. (2010). Reaching out with LibGuides: Establishing a working set of best practices. Journal of Library Administration, 50(5-6), 638-656. https://doi.org/10. 1080/01930826.2010.488941

Goodsett, M., Nawalaniec, T. M., \& Miles, M. (2020). Reimagining research guidance: Using a comprehensive literature review to establish best practices for developing LibGuides. Evidence Based Library and Information Practice, 15(1), 218-225. https://doi.org/10.18438/ eblip29679

Heinz, S., Linxen, S., Tuch, A. N., Fraßeck, L., \& Opwis, K. (2017). Is it still where I expect it? Users' current expectations of interface elements on the most frequent types of websites. Interacting with Computers, 29(3), 325-344. https://doi.org/10.1093/iwc/iww012

Hernandez, J. J., \& McKeen, L. (2015). Moving mountains: Surviving the migration to LibGuides 2.0. Online Searcher, 39(2), 16-22. https://www.infotoday.com/OnlineSearcher/ Articles/Features/Moving-Mountains-Surviving-the-Migration-to-LibGuides-102367. shtml

Holzinger, A., Scherer, R., \& Ziefle, M. (2011). Navigational user interface elements on the left side: Intuition of designers or experimental evidence? In P. Campos, N. Graham, J. Jorge, N. Nunes, P. Palanque, \& M. Winkler (Eds.), IFIP conference on human-computer interaction INTERACT 2011 (pp. 162-177). Springer. https://doi.org/10.1007/978-3-642-23771-3_13

Kalbach, J., \& Bosenick, T. (2003). Web page layout: A comparison between left-and right-justified site navigation menus. Journal of Digital Information. https://journals.tdl. org/jodi/index.php/jodi/article/view/94/93/www.audi.com

Kerico, J., \& Hudson, D. (2008). Using LibGuides for outreach to the disciplines. Indiana Libraries, 27(2), 40-42. https://journals.iupui.edu/index.php/IndianaLibraries/article/down load/17127/pdf_578

Kingsburg, J. R., \& Andre, A. D. (2004, September). A comparison of three-level web menu navigation structures. Proceedings of the Human Factors and Ergonomics Society Annual Meeting, 48(13), 1513-1517. https://doi.org/10.1177/154193120404801309

Logan, J., \& Spence, M. (2021). Content strategy in LibGuides: An exploratory study. The Journal of Academic Librarianship, 47(1), 102282. https://doi.org/10.1016/j.acalib.2020. 102282

Markman, K. M. (2016, March 8). Reimagining Harvard's LibGuides [Conference presentation]. Computers in Libraries, Washington, DC. http://conferences.infotoday.com/documents/ 220/B105_Markman.pdf

McCarthy, J. D., Sasse, M. A., \& Riegelsberger, J. (2004). Could I have the menu please? An eye tracking study of design conventions. In E. O’Neill, P. Palanque, \& P. Johnson (Eds.), People and computers XVII: Designing for society (pp. 401-414). Springer.

Murano, P., \& Oenga, K. K. (2012). The impact on effectiveness and user satisfaction of menu positioning on web pages. International Journal of Advanced Computer Science and Applications, 3(9), 206-212. https://doi.org/10.14569/ijacsa.2012.030931 
Murano, P., \& Sander, M. (2016). User interface menu design performance and user preferences: A review and ways forward. International Journal of Advanced Computer Science and Applications, 7(4), 355-361. https://doi.org/10.14569/ijacsa.2016.070447

Neuhaus, C., Cox, A., Gruber, A. M., Kelly, J., Koh, H., Bowling, C., \& Bunz, G. (2021). Ubiquitous LibGuides: Variations in presence, production, application, and convention. Journal of Web Librarianship, 15(3), 107-127. https://doi.org/10.1080/19322909.2021. 1946457

Ouellette, D. (2011). Subject guides in academic libraries: A user-centred study of uses and perceptions. Canadian Journal of Information and Library Science, 35(4), 436-451. https:// doi.org/10.1353/ils.2011.0024

Pionke, J. J., \& Manson, J. (2018). Creating disability LibGuides with accessibility in mind. Journal of Web Librarianship, 12(1), 63-79. https://doi.org/10.1080/19322909.2017.1396277

Pittsley, K. A., \& Memmott, S. (2012). Improving independent student navigation of complex educational web sites: An analysis of two navigation design changes in LibGuides. Information Technology and Libraries, 31(3), 52-64. https://doi.org/10.6017/ital.v31i3.1880

Pratt, J. A., Mills, R. J., \& Kim, Y. (2004). The effects of navigational orientation and user experience on user task efficiency and frustration levels. Journal of Computer Information Systems, 44(4), 93-100. https://doi.org/10.1080/08874417.2004.1164760

Salmerón, L., Mallouh, R. A., \& Kammerer, Y. (2017). Location of navigation menus in websites: An experimental study with Arabic users. Universal Access in the Information Society, 16(1), 191-196. https://doi.org/10.1007/s10209-015-0444-x

Sonsteby, A., \& DeJonghe, J. (2013). Usability testing, user-centered design, and LibGuides subject guides: A case study. Journal of Web Librarianship, 7(1), 83-94. https://doi.org/10. 1080/19322909.2013.747366

Springshare. (2021a). About Springshare. https://springshare.com/about.html Springshare. (2021b). LibGuides community. https://community.libguides.com/

Thorngate, S., \& Hoden, A. (2017). Exploratory usability testing of user interface options in LibGuides 2. College and Research Libraries, 78(6), 844-861. https://doi.org/10.5860/crl.78.6. 844 